\title{
PENGARUSUTAMAAN GENDER DI JEPANG UNTUK MENCAPAI SDG'S (SUSTAINABLE DEVELOPMENT GOALS) DALAM PERSPEKTIF FEMINISME LIBERAL
}

\author{
Intan Dwi Masrullah, Bagus Sigit Sunarko, Agung Purwanto \\ Program Studi Hubungan Internasional, Fakultas Ilmu Sosial dan Politik, \\ Universitas Jember \\ Jl. Kalimantan 37, Jember 68121 \\ E-mail : intandwi797@gmail.com
}

\begin{abstract}
Japan is one of the countries that has adopted the 2030 sustainable development agenda or SDG's (Sustainability Development Goals) by building an SDG's Promotion Headquarters to achieve balance in the country's development while protecting earth and eliminating poverty. Gender equality is a development target in the SDGs contained in point five. The increase in the elderly and the decline in the birth rate prompted the Japanese Government to take the initiative to increase the role of women in the public. However, the ranking of gender equality in Japan is ranked low globally. Therefore, to achieve the SDGs, the urgent goal that must be done is to address gender equality in Japan by integrating the concept of gender in policy and decision making.

In this study, the authors will describe the policies issued by the government in integrating gender and collect data on the gender gap that exists in Japan. By using the concept of gender mainstreaming in liberal feminism perspective, the author takes the initiative to find the causes of the factors that cause gender equality in Japan to be unsuccessful. Therefore, this study will explain some of the obstacles to gender equality by looking at what terms have not been implemented by Japan. The author has succeeded in finding that there are two factors that cause gender equality in Japan to be unsuccessful, there are the lack of commitment and understanding of gender by the government and regulatory agencies and the Gender Responsive Budget (ARG) which has no legal provisions.
\end{abstract}

Keywords: Gender Equality, SDG's, Gender Mainstreaming, Gender Gap.

\section{Pendahuluan}

SDG's atau Agenda Pembangunan Berkelanjutan 2030 merupakan kelanjutan pembangunan global MDG's sebagai agenda untuk mengatasi tantangan tambahan seperti kesetaraan, urbanisasi, kelestarian alam dan memiliki tujuan memperkuat kemitraan global. SDG's mengembangkan tujuan dari MDG's yang semula hanya 8 target menjadi 17 target. Jepang sebagai negara maju ${ }^{1}$ yang bahkan

\footnotetext{
${ }^{1}$ Leo Agung, Sejarah Asia Timur 1 / Perpustakaan FIS, accessed July 30, 2021, //library.fis.uny.ac.id\%2Fopac\%2Findex.php\%3Fp\%3Dshow_detail\%26id\%3D2354.
} 
sudah melakukan pembangunan dan modernisasi sejak masa restorasi meiji pada 1866-1869 dalam mengejar ketertinggalan dari Negara Barat ${ }^{2}$ namun hingga kini masih memiliki masyarakat dengan kultur yang bersifat patriarkis. ${ }^{3}$

Peringkat kesetaraan gender di Jepang menempati peringkat ke-121 sangat rendah, sebagai bandingan lebih rendah daripada negara kita Indonesia yang menempati peringkat $85 .{ }^{4}$ Jepang sebagai negara yang berkontribusi dalam SDGs harus mewujudkan salah satu tujuan pembangunan berkelanjutan di mana peringkat kesetaraan gender yang telah dinyatakan oleh peringkat dunia tergolong sangat rendah. ${ }^{5}$ Gender equality dianggap penting sebagai prinsip untuk mencapai pembangunan berkelanjutan dan keadilan sejati bagi semua orang di dunia. ${ }^{6}$

Populasi Jepang yang diperkirakan akan menyusut 30\% serta rasio lansia akan mencapai $40 \%$ pada tahun 2060 menyebabkan perempuan dianjurkan untuk menikah dan memiliki anak. Karena jumlah bayi yang lahir pada tahun 2019 telah turun sekitar 5,9\% menjadi 864.000, sedangkan tingkat kematian meningkat sejak akhir Perang Dunia II mencapai angka hampir 1,4 juta. ${ }^{7}$ Fakta mengenai jumlah perempuan yang merupakan setengah dari populasi Jepang dan fakta mengenai penurunan populasi penduduk Jepang ini membuat Jepang harus bergerak untuk memanfaatkan pekerja perempuan sebagai salah satu potensi yang dapat meningkatkan perekonomian Jepang. ${ }^{8}$

Perempuan memiliki kesulitan untuk berpartisipasi dalam ranah publik karena ada beberapa sebab yang membuat mereka merasa tidak berkeinginan untuk melakukannya. Faktor-faktor tersebut adalah adanya Sexual Harassment atau pelecehan seksual yang banyak terjadi di tempat kerja dan adanya stereotip bahwa pekerjaan rumah dan mengasuh anak adalah pekerjaan perempuan. Perempuan Jepang menghabiskan waktu untuk pekerjaan rumah tangga rata-rata 225 menit per hari sedangkan laki-laki hanya 31 menit perhari. Sedangkan rata-rata pekerjaan rumah tangga yang dilakukan oleh perempuan dan laki-laki di negara-negara OECD adalah perempuan 208 menit per hari dan laki-laki 90 menit per hari. ${ }^{9}$

\footnotetext{
2 B Rihardi, Sri Handayani, and Sumarjono, "Zaibatsu's Role in Development of Japan in the Meiji's Emperor Period of Year 1868-1912 | JURNAL HISTORICA," accessed July 30, 2021, https://jurnal.unej.ac.id/index.php/JHIS/article/view/7908.

${ }^{3}$ Emiko Jozuka CNN CNN Video by Will Ripley, Yoko Wakatsuki, Dan Campisi and Hidetaka Sato, "Centuries Ago, Women Ruled Japan. What Changed?," CNN, accessed July 30, 2021, https://www.cnn.com/2019/04/27/asia/japan-female-rulers-akihito-abdication-intl/index.html.

4 "Global Gender Gap Report 2020," World Economic Forum, accessed July 30, 2021, https://www.weforum.org/reports/gender-gap-2020-report-100-years-pay-equality/.

${ }^{5}$ Yuko Aizawa, "Gender Equality in Japan Remains Bottom | NHK WORLD-JAPAN News," NHK WORLD, accessed July 30, 2021, https://www3.nhk.or.jp/nhkworld/en/news/backstories/335/.

6 "Gender Equality Issues," UNI Global Union, accessed July 30, 2021, https://www.uniglobalunion.org/groups/equal-opportunities/gender-equality-issues.

7 Laurel Wamsley, “Japan's Births Decline To Lowest Number On Record,” NPR, December 24, 2019, sec. Asia, https://www.npr.org/2019/12/24/791132555/japans-births-decline-to-lowest-number-on-record. 8 "Japan: Demographic Shift Opens Door to Reforms," IMF, accessed July 30, 2021, https://www.imf.org/en/News/Articles/2020/02/10/na021020-japan-demographic-shift-opens-door-toreforms.

${ }^{9}$ Aki Lida, "ResearchGate | Find and Share Research," ResearchGate, accessed July 30, 2021, https://www.researchgate.net/.
}

Pengarusutamaan Gender Di Jepang Untuk Mencapai Sdg’s (Sustainable Development Goals) Dalam Perspektif Feminisme Liberal 
Perdana Menteri Shinzo Abe mengadopsi kebijakan womenomic's di mana kebijakan ini memiliki tujuan menciptakan lingkungan di mana perempuan dapat bersinar. Namun, sekalipun kebijakan womenomic's Abe terkenal feminis dan sangat peduli dengan isu-isu perempuan, akan tetapi dalam prakteknya masih banyak menyisakan kesenjangan gender dalam lingkungan sosial, ekonomi dan politiknya. Peringkat kesetaraan gender di Jepang juga masih berada dalam angka terendah dibandingkan dengan negara maju lainnya. Masalah dalam penelitian ini dipilih karena penulis tertarik untuk meneliti apa yang sebenarnya menyebabkan kesetaraan gender di Jepang tergolong dalam kategori yang rendah dan kebijakan pemerintah apa yang belum terealisasi.

Sesuai dengan latar belakang yang telah diuraikan sebelumnya, langkah selanjutnya adalah menguraikan dan mengidentifikasi permasalahan. Identifikasi permasalahan penting untuk mengetahui kesenjangan (gap) apa yang terdapat dalam topik pada penelitian ini. Maka, permasalahan dirumuskan sebagai berikut: Mengapa upaya yang dilakukan Pemerintah Jepang dalam memperjuangkan kesetaraan gender belum sepenuhnya terealisasi?

\section{Landasan Pemikiran}

Jurnal ini akan membahas mengenai faktor apa yang menyebabkan kesetaraan gender di Jepang belum berhasil sehingga menyebabkan peringkat kesetaraan gender Jepang secara global rendah dan peluang untuk mencapai target SDG's 2030 mendatang tidak terpenuhi. Dengan menggunakan konsep pengarusutamaan gender, penulis akan mengurakan dari beberapa prasyarat pengarusutamaan gender tersebut apakah telah diimplementasikan atau belum dalam setiap kebijakan di Jepang.

\section{Konsep Pengarusutamaan Gender}

Definisi oleh Dewan Eropa, PBB dan Uni Eropa mengenai Pengarusutamaan gender (Gender Mainstreaming) adalah bahwa tujuan pengarusutamaan gender bukan hanya tentang kesetaraan gender namun bagaimana mencapainya. Pengarusutamaan bukan sebuah program atau kegiatan, namun sebuah strategi pembangunan untuk mencapai keadilan dan kesetaraan. ${ }^{10}$ Gender Mainstreaming dapat dilihat sebagai pendekatan yang paling modern dalam Kesetaraan gender. Pendekatan pengarusutamaan gender berupaya melembagakan kesetaraan dengan menanamkan praktik dan norma yang peka gender dalam struktur, proses, dan lingkungan kebijakan publik. Pengarusutamaan gender terutama didasarkan pada strategi perubahan, yang berupaya mengatasi ketidaksetaraan gender dengan memfokuskan upaya pada budaya organisasi, proses dan struktur, terutama yang terkait dengan

10 "Direktorat Jenderal Kekayaan Negara, Kementerian Keuangan Republik Indonesia," accessed July 30, 2021, https://www.djkn.kemenkeu.go.id/.

134 Pengarusutamaan Gender Di Jepang Untuk Mencapai Sdg's (Sustainable Development Goals) Dalam Perspektif Feminisme Liberal 
pembuatan kebijakan. ${ }^{11}$ Penelitian berbasis gender dan penelitian berbasis feminisme pada hakekatnya merupakan dua hal yang berbeda. Dalam penelitian ini penulis memilih untuk melakukan penelitian berbasis gender dengan didasarkan pada perspektif yang dikembangkan oleh feminisme liberal. Penelitian ini secara spesifik akan memberikan fokus pada relasi kuasa antara laki-laki dan perempuan terkait peran yang dijalankannya berbasis pada aspek gender.-Sebagaimana lazimnya dalam dinamika perkembangan teori, feminisme liberal ini juga mendapatkan kritik dari kelompok feminis lain. Salah satu kritik tersebut misalnya, datang dari feminisme radikal yang berasumsi bahwa penindasan perempuan sebenarnya terjadi bukan karena perbedaan fasilitas ataupun tidak adanya regulasi yang memberikan kesempatan kepada perempuan. Dominasi laki-laki menurut kelompok feminisme radikal lahir faktor seperti adat, tradisi dan budaya, serta tubuh dan fisiologis perempuan, yang menyebabkan terjadinya penindasan terhadap perempuan. Merujuk pada adanya perbedaan cara pandang dari kalangan feminis sebagaimana contoh di atas, penulis memandang perlu untuk menegaskan bahwa kajian dalam skripsi ini dilakukan berdasar perspektif feminisme liberal.

Prasyarat untuk penerapan strategi pengarusutamaan gender:

Pemahaman dan komitmen dari pihak berwenang agar dapat menciptakan lingkungan yang memungkinkan untuk implementasi pengarusutamaan gender. Dalam pidatonya di Global Leader's Meeting 2017, PM Shinzo Abe mengatakan bahwa ia akan menciptakan "Lingkungan di mana Wanita dapat Bersinar". ${ }^{12}$ Dalam pengimplementasian SDG's, pemerintah Jepang juga telah menerapkan Prinsip-prinsip Panduan yang terdiri dari delapan area prioritas dan kebijakan yang salah satunya adalah Pemberdayaan Semua Orang (Empowerment of All People). Target-target dalam kebijakan ini adalah merealisasikan secara dinamis keterlibatan semua warga, promosi peran perempuan dalam masyarakat, tindakan terhadap kemiskinan anak, bantuan untuk penyandang disabilitas untuk partisipasi sosial dan kemandirian dan promosi pendidikan berkualitas.

\footnotetext{
${ }^{11}$ Mary Daly, "Gender Mainstreaming in Theory and Practice," Social Politics: International Studies in Gender, State \& Society 12, no. 3 (October 1, 2005): 433-50, https://doi.org/10.1093/sp/jxi023.

12 "UN Women - United Nations Entity for Gender Equality and the Empowerment of Women," UN Women, accessed July 30, 2021, https://www.unwomen.org/en.
}

Pengarusutamaan Gender Di Jepang Untuk Mencapai Sdg's (Sustainable Development Goals) Dalam 
a. Sistem informasi dan data terpilah berdasarkan jenis kelamin untuk mendokumentasikan perbedaan dalam situasi dan peluang antara perempuan dan laki-laki untuk memberikan dasar bagi pengembangan dan evaluasi kebijakan dan program.

Kementerian Dalam Negeri dan Komunikasi Pemerintah Jepang telah bekerja sama dengan Divisi Statistik PBB (UNSD) untuk menyelenggarakan Forum Global ke-7 tentang statistik gender dibawah Program Statistik Gender Global dan bimbingan dari Badan-antar dan Ahli Kelompok Statistik Gender (IAEG-GS). Acara ini mempertemukan para produsen dan pengguna statistik gender dari kantor statistik nasional dan internasional. Forum ini akan menjadi kesempatan untuk membahas cara meningkatkan data dan bukti untuk kebijakan gender dalam konteks pembangunan berkelanjutan 2030 yang didalamnya terdapat meninjau ketersediaan data terpilah gender. ${ }^{13}$ Data terpilah gender dikumpulkan oleh Kantor Kabinet dan dipublikasikan dalam situs web setiap tahun serta dalam White paper tentang kesetaraan gender yang diadopsi oleh kabinet dan dilaporkan ke legislatif setiap tahun.

b. Adanya analisis gender yang akan digunakan sebagai data dalam proses penyusunan kebijakan, program, maupun kegiatan. Analisis gender dapat dilakukan melalui indikator APKM (akses, partisipasi, kontrol dan manfaat). Terdapat faktor penghambat dalam internal (pemerintah) atau eksternal (masyarakat). Pemberian upah pekerjaan paruh waktu di Jepang awalnya sangat murah kepada ibu rumah tangga. ${ }^{14}$ Seluruh kebijakan terkait perempuan sudah diperbarui khususnya pada masa jabatan Shinzo Abe. Namun beberapa petinggi masih belum dalam tingkat responsif gender dan masih dalam fase netral gender. Contohnya kasus penerimaan mahasiswa di Universitas Kedokteran Tokyo yang mengurangi nilai perempuan dan memasukkan tambahan poin kepada pelamar laki-laki adalah karena sebetulnya para petinggi tersebut mengetahui tentang gender namun tidak melakukan apa-apa dan masih melihat kondisi layaknya sebuah masyarakat. Kemudian, faktor eksternal yang terjadi di masyarakat adalah adanya stereotip atau pandangan yang masih menyebar luas bahwa perempuan harus merawat anak dan pekerjaan rumah sedangkan suamilah yang harus mencari nafkah (budaya patriarki).

\footnotetext{
${ }^{13}$ Statistic UN, “UNSD - Welcome to UNSD," accessed July 30, 2021, https://unstats.un.org/home/. ${ }^{14}$ Margarita Estévez-Abe, "An International Comparison of Gender Equality : Why Is the Japanese Gender Gap so Persistent?," Undefined, 2013, https://www.semanticscholar.org/paper/An-internationalcomparison-of-gender-equality-\%3A-is-Est\%C3\%A9vezAbe/ab6305ddf9d05590fbdf0510172543b0a48f9b7d.
}

136 Pengarusutamaan Gender Di Jepang Untuk Mencapai Sdg's (Sustainable Development Goals) Dalam Perspektif Feminisme Liberal 
c. Alokasi sumber daya yang memadai seperti Anggaran Responsif Gender (ARG) untuk mendukung struktur dan praktik yang diperlukan dalam kegiatan pengarusutamaan. Jepang merupakan salah satu negara dari negara OECD yang telah memperkenalkan anggaran ini.

\section{Metode Penelitian}

Metode penelitian dalam jurnal ini menggunakan metode penelitian kualitatif yang lebih menekankan pada makna daripada generalisasi. Hasil penelitian akan diuraikan dalam kata-kata tertulis atau dengan cara dinarasikan. Teknik pengumpulan datanya yaitu berupa pengumpulan studi pustaka. Teknik ini merupakan teknik pengumpulan data yang menggunakan sumber kumpulan literatur dari buku-buku, jurnal-jurnal ilmiah, laporan/report, artikel dan internet. Jenis data yang digunakan adalah data sekunder dengan cara mengumpulkan dan mengkoding (memilah) data yang telah valid dan terpercaya. Teknik analisis data dilakukan dengan cara mereduksi data yang telah dikumpulkan dengan memilih pokok-pokok yang penting. Kemudian dilakukan penyajian data dengan cara menyusun data hasil reduksi dengan tema dan pola yang tersusun. Terakhir yaitu mencari jawaban untuk menjawab rumusan masalah dan mendapatkan kesimpulan dari hasil penelitian.

Materi ini dibatasi hanya pembahasan pada implementasi kebijakan Pemerintah Jepang masa Agenda Pembangunan Berkelanjutan (SDGs). SDGs digunakan penulis sebagai acuan dan tujuan untuk mencapai target pembangunan kedepan agar tercapai lingkungan tanpa diskriminasi dan memberantas kemiskinan serta menunjang sistem untuk kehidupan mendatang. penulis membatasi waktu penelitian dimulai dari tahun 2015 hingga tahun 2020 Tahun 2015 merupakan tahun di mana Sustainable Development Goals (SDGs) diadopsi oleh Anggota Negara-negara United Nations termasuk Jepang. Pembahasan dalam penelitian ini fokus pada era SDGs di mana Pemerintah Jepang juga berkontribusi dalam pembangunan gender di negaranya. Upaya yang dilakukan pemerintah Jepang dalam mengangkat kesetaraan gender hingga sekarang masih banyak terjadi perdebatan dan perempuan di Jepang masih merasakan adanya ketidakadilan terutama di tempat mereka bekerja. Penelitian ini dibatasi hingga 2020 karena data update terakhir peringkat Kesetaraan Gender Dunia adalah bulan februari tahun 2020. Karena pada tahun 2020 peringkat Kesetaraan Gender Jepang di dunia masih belum juga meningkat, maka penelitian ini masih dapat dilanjutkan.

\section{Hasil Penelitian}

Pengarusutamaan Gender Di Jepang Untuk Mencapai Sdg's (Sustainable Development Goals) Dalam 
Berdasarkan empat aspek prasyarat dalam pengarusutamaan gender untuk mencapai kesetaraan gender, terdapat beberapa aspek yang menjadi penghambat pengarusutamaan gender dalam meningkatkan peringkat kesetaraan gender global di Jepang. Prasyarat-prasyarat ini yang akan digunakan untuk mengukur dan menganalisis apakah Jepang termasuk di dalamnya pemerintah, lembaga berwenang dan masyarakat sudah memenuhi prasyarat untuk memajukan kesetaraan gender. Jika ada satu prasyarat yang tidak terpenuhi atau tidak dilakukan oleh pihak berwenang, pemerintah maupun masyarakat, maka hal ini dinyatakan sebagai salah satu penghambat adanya kesenjangan gender dan penyebab peringkat kesetaraan gender di Jepang rendah. Dari keempat aspek yang dijadikan tolak ukur dalam mewujudkan kesetaraan gender, maka faktor yang akan diuraikan dibawah ini yaitu komitmen dan pemahaman pemerintah dan Anggaran Responsif Gender yang menyebabkan kesetaraan gender di Jepang belum terealisasi. Sementara faktor-faktor lainnya yaitu Data Terpilah Gender dan Analisis Gender tidak termasuk ke dalam kendala. Data terpilah gender selalu diterbitkan oleh Biro Kesetaraan Gender di bawah naungan Kantor Kabinet Jepang dalam websitenya dalam white paper setiap tahun. Sedangkan analisis gender di Jepang telah dilakukan beberapa kali untuk mengidentifikasi kesenjangan salah satunya dengan diadakannya symposium dari Program Pertukaran Jurnalis Wanita Asia Pasifik dengan menampilkan artikel-artikel yang ditulis oleh jurnalis perempuan, pengalaman tentang mereka dan isu-isu untuk mengatasi kemajuan perempuan di media. Mengidentifikasi kesenjangan juga telah ditindaklanjuti oleh pemerintah Jepang dengan adanya kebijakan womenomic's sebagai respon untuk memenuhi kebutuhan laki-laki dan perempuan dan fokus terhadap kesetaraan gender di Jepang.

Berikut akan dijelaskan faktor-faktor yang menjadi kendala dalam merealisasikan kesetaraan gender di Jepang melalui konsep pengarusutamaan gender.

\section{Kurangnya Pemahaman dan Komitmen dari Pihak Berwenang dan Pemerintah}

Perdana Menteri Shinzo Abe berpidato dalam Pertemuan Pimpinan Global tentang kesetaraan gender dan pemberdayaan perempuan pada 27 September 2015 bahwa pilar fundamental kebijakannya adalah terwujudnya masyarakat di mana perempuan dapat bersinar. Artinya, Jepang akan memberlakukan undang-undang baru untuk mempromosikan keterlibatan aktif perempuan dalam masyarakat. Tujuannya adalah menciptakan masyarakat yang biasa bagi laki-laki dan perempuan untuk 
berbagi tanggung jawab atas pekerjaan mencari nafkah, pekerjaan rumah tangga, dan mengasuh anak sambil mengatasi tantangan yang terkait dengan masyarakat yang menua dan tingkat kelahiran yang rendah di hadapan seluruh dunia dengan tetap mewujudkan pertumbuhan ekonomi. Target SDG's 2030, Pemerintah Jepang akan berkontribusi dalam menciptakan dunia di mana kesetaraan gender dan partisipasi perempuan menjadi standar, dan baik laki-laki maupun perempuan bersinar secara alami dan setara. ${ }^{15}$

Namun terlepas dari pernyataan Abe tersebut, Jepang masih memiliki beberapa cara untuk melangkah seperti meningkatkan peringkat keserataan gender global yang rendah. Jepang berada di urutan 165 dari 193 negara dalam perwakilan parlemen perempuan. Berkebalikan dengan apa yang menjadi komitmen Abe di mana ia ingin memberikan kesempatan untuk perempuan bersinar, Abe hanya menunjuk satu menteri perempuan untuk 19 anggota Kabinet pada Oktober 2018. Abe menyatakan bahwa berkat dorongannya untuk reformasi drastis dalam perawatan dan gaya kerja, perekonomian Jepang telah tumbuh lebih dari 10 persen. Namun, ia sama sekali tidak membahas mengenai peringkat global Jepang yang mengerikan dalam pidatonya di awal pertemuan dua hari di antara para aktivis pembicara, peraih Nobel Malala Yousafzai 21 tahun, seorang aktivis Pakistan untuk pendidikan perempuan, dan mantan Presiden Chili Michelle Bachelet, sekarang Komisaris Tinggi PBB untuk Hak Asasi Manusia. ${ }^{16}$

Shinzo Abe merupakan Perdana Menteri Jepang yang telah menjabat sejak Desember 2012 dan merupakan ketua Partai Demokrat Liberal (LDP). Partai ini memenangi 71 dari 124 kursi di majelis tinggi. LDP berkuasa sejak 2012 yang mendapatkan suara mayoritas sehingga dapat membuat kebijakan dengan basis politik yang kuat. ${ }^{17}$ Berbeda dengan komitmen Shinzo Abe sebagai Perdana Menteri dan

15 “Speech by Prime Minister Shinzo Abe at Global Leaders Meeting on Gender Equality and Women's Empowerment (Speeches and Statements by the Prime Minister) | Prime Minister of Japan and His Cabinet," accessed July 30, 2021, https://japan.kantei.go.jp/97_abe/statement/201509/1213045_9928.html. ${ }^{16}$ Walter Sim, "Japan PM Shinzo Abe Touts Strides in Gender Equality despite Poor Global Rankings," Text, The Straits Times, March 23, 2019, https://www.straitstimes.com/asia/east-asia/japan-pm-shinzo-abetouts-strides-in-gender-equality-despite-poor-global-rankings.

${ }^{17}$ Budi Riza, "PM Jepang Shinzo Abe Menangi Pemilu Majelis Tinggi," Tempo, July 23, 2019, https://dunia.tempo.co/read/1227315/pm-jepang-shinzo-abe-menangi-pemilu-majelis-tinggi.

Pengarusutamaan Gender Di Jepang Untuk Mencapai Sdg's (Sustainable Development Goals) Dalam 
ketua LDP bahwa ia akan meningkatkan perwakilan perempuan dalam kursi parlemen. Namun, dari kewenangan LDP untuk memberikan afirmasi bagi perempuan menduduki kursi politik sangat minim.

Baru-baru ini Yoshihide Suga telah memenangkan pemilihan ketua presiden LDP dan menggantikan Shinzo Abe sebagai Perdana Menteri. Suga mendapatkan dukungan dengan berhasil mengumpulkan suara dari anggota LDP yang merupakan anggota Diet. Partai pada 1 September memutuskan untuk tidak melakukan pemilihan dari surat suara yang diberikan anggota dan pendukung partai lain yang dikatakan lebih mewakili keinginan masyarakat umum. Namun, partai menggunakan rumus sederhana penghitungan suara hanya dari anggota Diet dan tiga perwakilan dari masing-masing prefektur. Pimpinan eksekutif partai menolak 145 anggota LDP Diet yang kebanyakan lebih muda untuk mengeluarkan petisi yang ditandatangani untuk mengizinkan anggota partai non diet dalam memberikan suara mereka. Permintaan dari 10 cabang prefektur juga mendapatkan penolakan, termasuk Kanagawa dan Osaka. ${ }^{18}$

Sebelum Kepala Sekretaris Kabinet Yoshihide Suga, mantan Menteri Pertahanan Shigeru Ishiba dan mantan Menteri Luar Negeri Fumio Kishida mencalonkan diri sebagai ketua LDP menggantikan Abe, ada beberapa perempuan yang berusaha untuk mengikuti perlombaan untuk kepemimpinan LDP. Mereka adalah Tomomi Inada mantan Menteri Pertahanan serta anak didik Abe dan Seiko Noda Mantan Menteri Urusan dalam Negeri. Keduanya menunjukkan minat yang kuat untuk mencalonkan diri namun tidak ada yang dapat memenuhi persyaratan untuk mendapatkan nominasi dari setidaknya 20 anggota parlemen LDP. Sebelumnya, Inada mendapat dukungan dari anggota LDP yang memilliki pandangan konservatif tentang masalah keluarga, namun setelah ia mengalihkan fokusnya ke masalah seputar perempuan dan mulai mempromosikan debat tentang membantu ibu tunggal serta mengizinkan nama keluarga terpisah untuk pasangan yang sudah menikah, anggota LPD menjauhkan diri dan berpaling dari Inada. Inada dalam program TV yang direkam pada hari Rabu 16 September 2020 mengatakan bahwa politik yang dipimpin fraksi adalah rintangan bagi perempuan untuk mengikuti perlombaan dalam kepemimpinan. Inada akhirnya memutuskan untuk

\footnotetext{
18 "EDITORIAL: LDP Again Puts Power Structure over Intraparty Democracy | The Asahi Shimbun: Breaking News, Japan News and Analysis," The Asahi Shimbun, accessed July 30, 2021, https://www.asahi.com/ajw/articles/13689486.
}

140 Pengarusutamaan Gender Di Jepang Untuk Mencapai Sdg's (Sustainable Development Goals) Dalam Perspektif Feminisme Liberal 
mengikuti kebijakan fraksi mendukung Yoshihide Suga yang telah mendapatkan dukungan dari sekitar 80 persen anggota parlemen.

Begitu pula yang terjadi pada Seiko Noda. Ia dengan sangat terbuka mengatakan ingin menjadi perdana menteri namun gagal mendapatkan dukungan dari 20 anggota parlemen LDP dalam dua pemilihan kepemimpinan sebelumnya. Namun hanya beberapa hari setelah pengumuman pengunduran diri Abe, sebagian besar faksi LDP telah memutuskan untuk mendukung Suga. Ishiba dan Kishida mengumumkan pencalonan mereka dengan mendapatkan dukungan dari kelompok intrapartai mereka. Shin Ki-Young, seorang Profesor Ilmu Politik di Universitas Ochanomizu mengatakan bahwa adanya langit-langit Kaca disebabkan karena perempuan tidak dapat mengikuti perlombaan kecuali mereka telah memegang jabatan penting di masa lalu dan mendapatkan dukungan dari faksi. Shin juga mengingatkan bahwa situasi seperti itu dapat menghambat upaya untuk mengangkat masalah yang berkaitan dengan perempuan. ${ }^{19}$

Partai LDP yang berkuasa sejak 2012 mendapatkan suara mayoritas dan memiliki kewenangan untuk membuat kebijakan dengan basis politik yang kuat. Oleh sebab itu, LDP memiliki pengaruh kuat dalam mencapai posisi puncak kepemimpinan dalam pemerintahan di Jepang. Namun, analisis yang saya temukan bahwa petinggi-petinggi dalam partai LDP memiliki komitmen yang rendah akan kesetaraan gender di Jepang. Seperti yang telah disebutkan sebelumnya oleh Tomomi Inada bahwa untuk dapat menjadi presiden LDP, seseorang harus mendapatkan dukungan dari kurang lebih 20 anggota partai. Sedangkan di dalam LDP, politik dipimpin olek faksi dan setiap faksi-faksi memiliki kecenderungan untuk mendukung calon kandidat yang telah disepakati sebelumnya oleh anggota faksi untuk dipilih. Oleh karena itu, bukan hanya langit-langit kaca yang harus dihancurkan, namun langitlangit baja yang harus ditembus oleh perempuan-perempuan Jepang.

\footnotetext{
${ }^{19}$ KYODO NEWS, "FOCUS: Again, No Female Contenders in Japan's Leadership Race," Kyodo News+, accessed July 30, 2021, https://english.kyodonews.net/news/2020/09/ded21b9639cc-focus-again-nofemale-contenders-in-japans-leadership-race.html.
}

Pengarusutamaan Gender Di Jepang Untuk Mencapai Sdg's (Sustainable Development Goals) Dalam 


\section{Anggaran Resonsif Gender (ARG) sebagai Dana untuk Menjalankan Kebijakan Terkait Gender yang Belum Dijalankan}

Ketika melaksanakan sebuah proyek atau program, anggaran dana selalu menjadi unsur penting terlaksananya kegiatan. Jika anggaran dana tidak ada, maka program tersebut tidak akan berjalan. Begitu pula dengan kegiatan-kegiatan yang berbasis gender, anggaran responsif gender (ARG) diperlukan untuk menunjang berjalannya suatu program atau kebijakan yang menggunakan gender sebagai perspektif kebijakan. Chakraborty melakukan survei pada tahun 2016 terhadap 26 negara Asia dalam kegiatan penganggaran gender dan menemukan dari beberapa negara ini yaitu Brunei, Cina, Hongkong, Myanmar, Papua Nugini, Singapura, Taiwan dan termasuk Jepang belum menerapkan Anggaran yang Responsif Gender. ${ }^{20}$

Walaupun Jepang merupakan negara yang telah memperkenalkan anggaran responsif gender dalam setiap pengambilan keputusan, akan tetapi Jepang belum memiliki ketentuan hukum yang mendasari praktik ini. LSM perempuan di Jepang yaitu Japanese Women's Watch (JAWW) juga telah melakukan kegiatan terkait anggaran responsif gender, namun kemajuan berjalan lambat karena kelompok LSM ini bersifat sukarela dan memiliki sumber daya yang kurang. Pada tahun 2008, menjelang perumusan Rencana Dasar Ketiga untuk Kesetaraan Gender Jepang, LSM perempuan Jepang melobi dan memberikan tekanan pada pemerintah pusat untuk memasukkan Anggaran Responsif Gender ke dalam rencana tersebut. Namun politisi dari LDP yang 'anti feminis' yaitu Jinja Honcho (Asosiasi Kuil Shinto) dan akademisi konservatif berusaha untuk mencabut undang-undang tentang kesetaraan gender. Walaupun akhirnya LSM perempuan mendapat dukungan dari Menteri Kesetaraan Gender untuk memasukkan anggaran responsif gender untuk dimasukkan dalam Rencana Dasar Ketiga untuk kesetaraan gender, namun faktanya rencana ini tidak mengikat secara hukum. ${ }^{21}$

Sebagian besar dana yang dialokasikan untuk melaksanakan proyek Rencana Dasar Masyarakat Setara Gender digunakan untuk mendukung kaum lanjut usia sekitar 80 hingga 60 persen. Anggaran ini dikelola oleh Kementerian Kesehatan, Tenaga Kerja dan Kesejahteraan. Pada tahun 2000, seorang

\footnotetext{
${ }^{20}$ Lekha Chakraborty, Marian Ingrams, and Singh, "Working Papers · Grow Research Series," accessed July 30, 2021, http://grow.research.mcgill.ca/working-papers/.

${ }^{21}$ R. Ichii and R. Sharp, "Government Budgets and the Promotion of Gender Equality in Japan and South Korea," Undefined, 2013, https://www.semanticscholar.org/paper/Government-budgets-and-thepromotion-of-gender-in-Ichii-Sharp/7d6fd0256bab9f2784a164bf2ddd7be5565e8990.
}

142 Pengarusutamaan Gender Di Jepang Untuk Mencapai Sdg's (Sustainable Development Goals) Dalam Perspektif Feminisme Liberal 
anggota parlemen bertanya mengapa lebih dari 80 persen anggaran untuk masyarakat yang setara gender dialokasikan untuk dukungan keuangan bagi kaum lanjut usia. Sekretaris Kabinet menjawab bahwa anggaran ini sudah termasuk dalam Rencana Dasar Kesetaraan Gender yang pertama. Pada tahun 2004 anggota Komite Spesialis juga menanyakan pertanyaan yang sama kepada Biro Kesetaraan Gender. Biro tersebut menjawab bahwa jumlah wanita lanjut usia semakin meningkat dan juga wanita cenderung lebih banyak memberikan perawatan kepada orang lanjut usia. Pada tahun 2006 biro tersebut mengulangi jawaban yang sama ketika sebuah pertanyaan diajukan oleh kelompok perempuan. ${ }^{22}$ Biro tersebut berasumsi bahwa, karena perempuan hidup lebih lama daripada laki-laki, perempuan lebih mungkin mendapat manfaat dari program dukungan keuangan. Namun, rata-rata pensiun per bulan yang diterima perempuan jauh lebih sedikit dibandingkan laki-laki, bahkan ketika perempuan tersebut memiliki pekerjaan penuh waktu. Wanita biasanya memiliki waktu istirahat dari pekerjaan karena kehamilan dan pengasuhan anak dan periode tidak bekerja ini mempengaruhi tunjangan pensiun mereka. Masalah-masalah ini menunjukkan perlunya anggaran untuk diteliti lebih cermat dari perspektif gender. ${ }^{23}$

\section{KESIMPULAN}

Pengarusutamaan gender merupakan strategi untuk mengintegrasikan gender sebagai suatu kebijakan. Dalam melakukan pengarusutamaan gender perlu memenuhi beberapa prasyarat agar proses pengarusutamaan gender sebagai suatu kebijakan benar-benar mempertimbangkan pola perilaku setiap individu dengan menanamkan praktik yang peka gender di setiap pengambilan keputusan. Terdapat empat prasyarat dari pengarusutamaan gender yang digunakan dalam menganalisis kesetaraan gender dalam suatu negara. Prasyarat-prasyarat tersebut adalah adanya komitmen pemerintah dan lembaga berwenang, tersedianya data terpilah gender, adanya anggaran responsif gender dan adanya analisis gender. Prasyarat tersebut digunakan untuk menilai bagaimana proses pengarusutamaan gender di

\footnotetext{
22 “北京JAC (Japan Accountability Caucus for the Beijing Conference),” accessed July 30, 2021， http://pekinjac.or.tv/.

${ }^{23}$ Toko Shirakawa, "Japan an Underdeveloped Country for Women | The Japan Times," January 2019, https://www.japantimes.co.jp/opinion/2019/01/11/commentary/japan-commentary/japanunderdeveloped-country-women/\#.Xrtzu2gzbMV.
}

Pengarusutamaan Gender Di Jepang Untuk Mencapai Sdg's (Sustainable Development Goals) Dalam 
Jepang dengan menganalisis program atau kebijakan pemerintah dan apa yang terjadi di masyarakat sehingga kesetaraan gender di Jepang belum terealisasi.

Sesuai dengan penelitian yang telah dilakukan dalam skripsi ini, dari keempat prasyarat tersebut, Jepang belum melakukan beberapa prasyarat sehingga menghambat kesetaraan gender dan membuat peringkat kesetaraan gender di Jepang stuck di golongan peringkat bawah. Dari keempat prasyarat yang menjadi penghambat kesetaraan gender di Jepang rendah diantaranya adalah kurangnya komitmen dan pemahaman pemerintah serta lembaga berwenang dan anggaran responsif gender yang belum ada ketentuan hukumnya Kurangnya pemahaman dari pemerintah dan lembaga berwenang terdapat dalam sistem pemilihan kandidat dalam suatu partai di mana faksi-faksi memiliki pengaruh besar untuk memilih kandidat yang akan mereka pilih untuk menempati posisi tertinggi dalam parlemen. Perempuan akan sulit mendapatkan posisi tersebut jika sebelumnya mereka tidak memiliki pengaruh dan posisi tinggi dalam jabatan mereka. Anggaran untuk gender di Jepang belum memiliki ketentuan hukumnya sehingga sulit untuk menjalankan kebijakan-kebijakan yang terkait dengan gender.

Jika kedua prasyarat itu belum juga mengalami perkembangan, maka sangat mustahil Jepang dapat memenuhi target SDG's 2030 mendatang karena kesetaraan gender merupakan salah satu pilar yang harus diprioritaskan. Setiap satu pilar dalam SDG's akan mempengaruhi pembangunan terhadap pilar lainnya. Jepang sebagai negara yang mengadopsi pembangunan berkelanjutan wajib untuk mencapai semua target dalam 17 pilar SDG's.

\section{Daftar Pustaka}

Agung, Leo. Sejarah Asia Timur 1 | Perpustakaan FIS. Accessed July 30, 2021.

//library.fis.uny.ac.id\%2Fopac\%2Findex.php\%3Fp\%3Dshow_detail\%26id\%3D2354.

Aizawa, Yuko. "Gender Equality in Japan Remains Bottom | NHK WORLD-JAPAN News.” NHK WORLD. Accessed July 30, 2021.

https://www3.nhk.or.jp/nhkworld/en/news/backstories/335/.

144 Pengarusutamaan Gender Di Jepang Untuk Mencapai Sdg's (Sustainable Development Goals) Dalam Perspektif Feminisme Liberal 
Chakraborty, Lekha, Marian Ingrams, and Singh. "Working Papers • Grow Research Series."

Accessed July 30, 2021. http://grow.research.mcgill.ca/working-papers/.

CNN, Emiko Jozuka, CNN Video by Will Ripley, Yoko Wakatsuki, Dan Campisi and Hidetaka Sato. “Centuries Ago, Women Ruled Japan. What Changed?” CNN. Accessed July 30, 2021. https://www.cnn.com/2019/04/27/asia/japan-female-rulers-akihito-abdicationintl/index.html.

Daly, Mary. "Gender Mainstreaming in Theory and Practice." Social Politics: International Studies in Gender, State \& Society 12, no. 3 (October 1, 2005): 433-50. https://doi.org/10.1093/sp/jxi023.

“Direktorat Jenderal Kekayaan Negara, Kementerian Keuangan Republik Indonesia.” Accessed July 30, 2021. https://www.djkn.kemenkeu.go.id/.

The Asahi Shimbun. "EDITORIAL: LDP Again Puts Power Structure over Intraparty Democracy I The Asahi Shimbun: Breaking News, Japan News and Analysis.” Accessed July 30, 2021. https://www.asahi.com/ajw/articles/13689486.

Estévez-Abe, Margarita. "An International Comparison of Gender Equality : Why Is the Japanese Gender Gap so Persistent?" Undefined, 2013. https://www.semanticscholar.org/paper/Aninternational-comparison-of-gender-equality-\%3A-is-Est\%C3\%A9vezAbe/ab6305ddf9d05590fbdf0510172543b0a48f9b7d.

UNI Global Union. “Gender Equality Issues.” Accessed July 30, 2021.

https://www.uniglobalunion.org/groups/equal-opportunities/gender-equality-issues.

World Economic Forum. “Global Gender Gap Report 2020.” Accessed July 30, 2021. https://www.weforum.org/reports/gender-gap-2020-report-100-years-pay-equality/.

Ichii, R., and R. Sharp. "Government Budgets and the Promotion of Gender Equality in Japan and South Korea.” Undefined, 2013. https://www.semanticscholar.org/paper/Government- 
budgets-and-the-promotion-of-gender-in-Ichii-

Sharp/7d6fd0256bab9f2784a164bf2ddd7be5565e8990.

IMF. “Japan: Demographic Shift Opens Door to Reforms.” Accessed July 30, 2021.

https://www.imf.org/en/News/Articles/2020/02/10/na021020-japan-demographic-shiftopens-door-to-reforms.

Lida, Aki. "ResearchGate | Find and Share Research." ResearchGate. Accessed July 30, 2021. https://www.researchgate.net/.

NEWS, KYODO. "FOCUS: Again, No Female Contenders in Japan’s Leadership Race.” Kyodo News+. Accessed July 30, 2021. https://english.kyodonews.net/news/2020/09/ded21b9639cc-focus-again-no-femalecontenders-in-japans-leadership-race.html.

Rihardi, B, Sri Handayani, and Sumarjono. 'Zaibatsu's Role in Development of Japan in the Meiji's Emperor Period of Year 1868-1912 | JURNAL HISTORICA.” Accessed July 30, 2021. https://jurnal.unej.ac.id/index.php/JHIS/article/view/7908.

Riza, Budi. “PM Jepang Shinzo Abe Menangi Pemilu Majelis Tinggi.” Tempo, July 23, 2019. https://dunia.tempo.co/read/1227315/pm-jepang-shinzo-abe-menangi-pemilu-majelis-tinggi.

Shirakawa, Toko. "Japan an Underdeveloped Country for Women | The Japan Times," January 2019. https://www.japantimes.co.jp/opinion/2019/01/11/commentary/japancommentary/japan-underdeveloped-country-women/\#.Xrtzu2gzbMV.

Sim, Walter. "Japan PM Shinzo Abe Touts Strides in Gender Equality despite Poor Global Rankings.” Text. The Straits Times, March 23, 2019. https://www.straitstimes.com/asia/eastasia/japan-pm-shinzo-abe-touts-strides-in-gender-equality-despite-poor-global-rankings.

“Speech by Prime Minister Shinzo Abe at Global Leaders Meeting on Gender Equality and Women's Empowerment (Speeches and Statements by the Prime Minister) | Prime Minister of Japan 
and His Cabinet." Accessed July 30, 2021.

https://japan.kantei.go.jp/97_abe/statement/201509/1213045_9928.html.

UN, Statistic. "UNSD - Welcome to UNSD.” Accessed July 30, 2021.

https://unstats.un.org/home/.

UN Women. "UN Women - United Nations Entity for Gender Equality and the Empowerment of Women.” Accessed July 30, 2021. https://www.unwomen.org/en.

Wamsley, Laurel. “Japan’s Births Decline To Lowest Number On Record.” NPR, December 24, 2019, sec. Asia. https://www.npr.org/2019/12/24/791132555/japans-births-decline-to-lowestnumber-on-record.

“北京JAC (Japan Accountability Caucus for the Beijing Conference).” Accessed July 30, 2021. http://pekinjac.or.tv/. 